Egyptian Poultry Science Journal

http://www.epsaegypt.com

ISSN: 1110-5623 (Print) - 2090-0570 (On line)

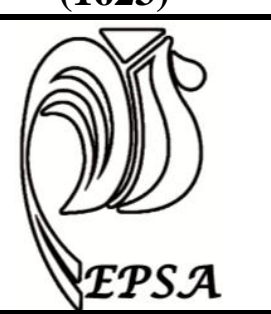

\title{
EFFECT OF LOW-PROTEIN IN ISO-ENERGETIC DIETS ON PERFORMANCE, CARCASS CHARACTERISTICS, DIGESTIBILITIES AND PLASMA LIPIDS OF BROILER CHICKENS
}

\author{
A. A. Saleh \\ Dep. of Poult. Prod., Fac. of Agric., Kafrelsheikh Univ., 333516 Kafr El-Sheikh, Egypt
}

Received: 24/ 01/2016

Accepted: 24/02/2016

\begin{abstract}
This study was conducted to determine the effect of low or high protein diets with constant ME on growth performance, carcass characteristics, digestibilities and blood parameters of Cobb Avian 48 broilers from 1 to $34 \mathrm{~d}$ of age. A total number of 2080 one-day-old chicks were housed randomly in 16 pens and divided into two experimental groups, each group divided into 8 replicates and each replicate has 130 birds/ pen. All birds were fed pre-starter diet (CP, 23\% and ME, $2950 \mathrm{kcal} / \mathrm{kg}$ ) for 4 days then the birds were divided into two experimental diets which were formulated to have 2 levels of $\mathrm{CP}$ respectively, in each phase: 22 and $21 \% \mathrm{CP}$ with $3050 \mathrm{kcal} / \mathrm{kg}$ in the starter phase (5 to 10 d); 20 and $19 \% \mathrm{CP}$ with $3100 \mathrm{kcal} / \mathrm{kg}$ in the grower phase (11 to $25 \mathrm{~d}$ ); and 19 and $18 \% \mathrm{CP}$ with $3180 \mathrm{kcal} / \mathrm{kg}$ in the finisher phase (26 to $34 \mathrm{~d}$ ). Digestible Lysine was maintained at $1.22,1.12$, and $0.96 \%$ of the diet in the starter, grower, and finisher periods, respectively. Body weight gain, feed intake and feed conversion as well as thigh and liver weights were not influenced by changing protein level in the diets. However, carcass weight and breast muscle weight were increased significantly $(\mathrm{P} \leq 0.05)$. On the other hand, abdominal fat weight was deceased $(\mathrm{P} \leq 0.05)$ by feeding low protein diet. Although, dry matter and crude fat utilization were not affected, while, crude protein and crude fiber utilization were improved by feeding low protein diets. Plasma GOT, GPT and total cholesterol were not changed, while; plasma HDL was increased by feeding low protein diets. Furthermore, it was observed a decrease in muscle and liver MDA by feeding low protein diets, indicating the improving of the anti-oxidative activities by decreasing the protein content in broiler diets. Economic efficiency was improved by feeding low protein diets compared to high protein diets. In conclusion, feeding Cobb Avian 48 broilers on 1\% lower protein diets than the strain recommendation, at constant ME, with the same amino acids levels had not adversely affected the growth performance, carcass parameters and liver functions, while; dietary crude protein and crude fiber utilization were improved.
\end{abstract}

Key words: Broilers, Low Protein, Digestibility, Growth Performance.

Corresponding author: ahmed.saleh1@agr.kfs.edu.eg, 


\section{INTRODUCTION}

Feeding broiler on low protein diets may reduce feed cost and allow for use of alternate feedstuffs and considered as one of the most important decisions for broiler nutritionists, because of the expense of providing sufficient protein to growing broilers. Numerous studies have been carried out to investigate the possibility of reducing dietary crude protein $(\mathrm{CP})$ levels. However, meeting the nutritional requirements for growing birds constitutes the majority of costs associated with poultry production (May et al., 1998), accounting for around 75 percent of the expense (Nakaue and Arscott, 1991), and certainly is becoming an issue of even greater significance as the prices of feed ingredients continue to rise. A large portion of that cost involves meeting the protein and amino acid requirements of birds (Corzo et al., 2004; Firman and Boling, 1998; Firman, 1994). By reducing the level of crude protein in the diet it is possible to achieve significant cost savings (Eits et al., 2005). Firman (1994) reported that it is possible to save five dollars per ton of feed by reducing the protein level in the diet of turkeys by one percent. In addition to reduce feed costs, the ability to lower crude protein in the diet can result in decreased nitrogen excretion (Kidd et al., 1996; Ferguson et al., 1994; Nahm, 2002; Namroud et al., 2008), improved ability to cope with heat stress, and allow for the use of a greater variety of feedstuffs (Kidd et al., 1996), which can be valuable in itself as a method to increase flexibility in the choice of locally available feedstuffs, potentially decreasing transportation costs. Findings on different levels of (CP) effect in iso-energetic diets on broiler metabolism and body composition is necessary in order to understand broilers' response to different levels of protein (Horniakova and Abas, 2009). However, some researcher's studies had found that reducing dietary crude protein does not affect growth performance (Parr and Summers, 1991; Moran and Stilborn, 1996). On the other hand, rate and efficiency of growth is lower, and carcass composition becomes inferior in broilers fed diets in which crude protein has been lowered by more than $2.5 \%$ of the chicken requirements, even when all known nutrient requirements are supplemented such as amino acids (Aletor et al., 2000; Bregendahl et al., 2002; Sterling et al., 2005; Waldroup et al., 2005a). Therefore, in the present study, an experiment was conducted to investigate the effect of feeding low or high $\mathrm{CP}$ diets at constant ME on growth performance, carcass characteristics, nutrients digestibilities and blood parameters of Cobb Avian 48 broilers.

\section{MATERIALS AND METHODS}

Birds and Housing: The animal experiment was conducted in accordance with the guideline of Kafrelsheikh University, Egypt. The experiment was conducted in an environmentally controlled house. A total number of 2080 one-day-old (Cobb Avian 48) broiler chickens were hosed randomly in 16 pens and divided into two experimental groups, each group divided to 8 replicates and each replicate had 130 birds/ pen. The chickens and diets were supplied from Fat- Hens Company, Tanta, Egypt. Birds were vaccinated against Newcastle disease virus on $6 \mathrm{~d}$ and $21 \mathrm{~d}$, and the birds were kept under standard management conditions; as feed and water were provided ad libitum throughout the experimental period. The whole experimental period was divided into 4 phases: pre-starter commercial diet ( 1 to 4 d), starter (5 to $10 \mathrm{~d}$ ), grower (11 to $25 \mathrm{~d}$ ), and finisher (26 to $34 \mathrm{~d}$ ). 


\section{Experimental Diets:}

The feed ingredients used for the formulation of experimental diets were analyzed in triplicate for their dry matter, crude protein, ether extract crude fiber content according to (AOAC, 1990). According to the nutrient recommendations of the Cobb Avian 48 management guide (2014), two experimental diets were formulated to have 2 levels of CP in the last phases of growth: 22 and $21 \% \mathrm{CP}$ with $3050 \mathrm{kcal} / \mathrm{kg}$ in the starter phase; 20and $19 \% \mathrm{CP}$ with $3100 \mathrm{kcal} / \mathrm{kg}$ in the grower phase; and 19and 18\% CP with 3180 $\mathrm{kcal} / \mathrm{kg}$ in the finisher phase (Table1). Digestible Lysine was maintained at 1.22, 1.12 , and $0.96 \%$ of the diet in the starter, grower, and finisher periods, respectively, and the limiting amino acids like Methionine, Threonine, and Tryptophan were included according to Cobb Avian 48 recommendations. Each experimental diet was offered randomly to 8 replicates, and the experimental diets were fed from 4 to $34 \mathrm{~d}$ of age.

\section{Data Collection:}

Feed intake and body weight gain were recorded at the end of each diet phase, accordingly weight gain and feed conversion ratio (FCR) were easily calculated. At the end of experiment, 3 birds from each replicate were randomly selected and slaughtered (24 bird/ treatment), and data on carcass yield calculated as \% of live body weight including deboned breast meat yield, thigh yield, abdominal fat, and relative weights of liver and heart were recorded. Mortality was also recorded during the entire experiment. At slaughtering, blood samples were collected into heparinised test tubes, quickly centrifuged at $5,900 \times \mathrm{g}$ for 10 minutes at $4^{\circ} \mathrm{C}$ to separate plasma, and stored at $-30^{\circ} \mathrm{C}$ until analysis. In the last three days of the experiment, excreta were collected from 24 bird/ treatment and weighed. Then the samples were dried in a drying oven at $60{ }^{\circ} \mathrm{C}$ for $24 \mathrm{~h}$. The complete dried samples were homogenized, sampled, and then finely ground to analyze for DM according to AOAC (1994). Crude protein content in diet and excreta was determined using the Kjeldahl method (AOAC ,1994) and crude fat was measured with Soxhlet according to Bligh and Dyer (1959). Digestion coefficients of nutrients were calculated for dry matter, crude protein, crude fiber and crude fat by analyses of the diets and collected excreta.

Plasma GOT, GPT, total cholesterol level (TC), high-density lipoprotein (HDL) were measured colorimetrically by using commercial kits (Diamond Diagnostics, Egypt) according to the procedures outlined by the manufacturer. Concentration of muscle Malondialdehyde (MDA) was measured by the method of Ohkawa et al., (1979).

Economical efficiency is defined as the net revenue per unit feed cost calculated from input output analysis as described by Hassan et al., (1996).

Statistical Analysis

The differences among treatments were statistically analyzed by T test using SPSS Statistics 17.0 (SPSS 2008). P $\leq 0.05$ was set as limit of significance.

\section{RESULTS AND DISCUSSION}

Five birds were died from each treatment during the experimental period. Data presented in Table 2 shows the effects of dietary high or low protein content on growth performance of broiler chickens. Feeding high or low dietary protein content did not influence body weight gain, feed intake and feed conversion. Considerable amounts of researches have been done to evaluate the effects of low-protein diets on the growth performance and carcass characteristics of broiler chickens. However, conflicting results from these studies do not allow a clear conclusion on the effects of these diets on practical broiler production. Trials evaluating the effect of low CP diets have reported inferior 
performance on broiler productivity however; others suggested no difference in growth by low protein diets. In this study, feeding high $(22,20,19 \%)$ or low $(21,19$, $18 \%$ ) diary protein did not affect growth performance. This is in agreement with different studies (Parr and Summers, 1991; Deschepper and De Groote, 1995; Moran and Stilborn, 1996; Yamazaki et al., 1996; Aletor et al., 2000; Kamran et al., 2010). On the other hand, Kamran et al., (2008) reported that feed intake was linearly increased with reduced $\mathrm{CP}$ diets during grower, finisher, and overall periods. Nevertheless, the preponderance of information suggests that feed efficiency and growth performance were reduced when the dietary $\mathrm{CP}$ level is reduced by more than 3\% from NRC (1994), even when all known nutrient requirements are met (Fancher and Jensen, 1989; Aletor et al., 2000; Bregendahl et al., 2002; Sterling et al., 2005; Waldroup et al., 2005b).

In this study, thigh and liver weights were not affected. However, carcass weight and breast muscle weight were increased significantly $(\mathrm{p}<0.05)$. On the other hand, abdominal fat weight was deceased by feeding low protein diet. Results of increased abdominal fat and decreased muscle weight by high protein diet are in complete agreement with Yamazaki et al., (1998); (2006); Moran and Stilborn (1996). One of the mechanisms involved in decreasing carcass fatness by feeding greater protein level diets is the associated increased heat increment involved in deamination and transamination of surplus amino acids to other metabolites and finally uric acid. Rosebrough et al., (2002) showed that increase of $\mathrm{CP}$ can dramatically decrease in vitro lipogenesis. They suggested that a combination of mRNA stability and posttranscriptional events interact to regulate lipogenesis in the chicken.

Data in Table 3 shows the effect of dietary high and low protein content on nutrients digestibility. Dry matter and crude fat digestibility were not affected by low or high diet protein content, on the other hand, crude protein and crude fiber digestibility were improved significantly $(\mathrm{p}<0.05)$ by lowering dietary protein content. These results agree with Dean et al.,(2006) and Namroud et al., (2008), who reported that with the reduction in crude protein ranging from just a few percentage points up to a $25 \%$ did not affect the growth performance and nutrients digestibility. Also, Bregendahl et al., (2002) reported that dry matter, crude protein and crude fat digestibility were not affected by changed protein when accept the chicken requirements. In this connection, studies of Blair et al., (1999); Aletor et al., (2000); Swennen et al., (2004) reported that the low protein utilization for broilers fed highprotein diets has been observed. However, Gong et al., (2005) found that no treatment differences were detected for dry matter, energy and crude protein digestibility by feeding low protein diet.

Plasma concentrations of GOT, GPT and total cholesterol (Fig.1. A, B,C) were not affected, however, Plasma HDL increased significantly $(\mathrm{P} \leq 0.05)$ (fig. $1 . \mathrm{D})$ by low protein diet. These result disagree with Gong et al., (2005) who found that serum cholesterol levels of broilers fed high dietary was higher $(\mathrm{p}<0.05)$ than low protein diet. The liver function enzymes as GOT and GPT were not affected by decreasing $1 \%$ of dietary protein indicating that decreasing $1 \%$ of dietary protein is still safe to the broilers. This result is in agreement with Dairo et al., (2010) who found that plasma GOT and GPT were not affected by decreasing dietary protein by $1 \%$.

Figure 2 shows the effect of feeding low or high protein diet on muscle and liver MDA concentration. Muscle and liver MDA concentration were decreased by feeding low protein diets, indicating an improving of the anti-oxidative activities 
by decreasing the protein content in broiler diets by $1 \% \mathrm{CP}$. In this respect, Jimoh et al., (2005) found a significant increase $(\mathrm{P}<$ $0.05)$ in the concentration of malondialdehyde in the tissues of animals fed very low protein diet (more than $5 \%$ ) is an indication of increased lipid peroxidation in those tissues.

Results of economic efficiency (E.E) for chicks fed experimental diets during the experiment period are summarized in Table 4. There is considerable cost saving with using low protein diets compared to high protein diet.

\section{CONCLUSION}

Feeding Cobb Avian 48 broilers on low protein diets at constant $\mathrm{ME}$ with same amino acids levels has not adversely affected the growth performance, carcass parameters and liver functions. While; protein utilization was improved with good impact on economical efficiency.

\section{ACKNOWLEDGEMENT}

We are grateful to FAT- HENS Company, Egypt for supplying broiler chicks and experimental diets.

Table (1): Composition and nutrient analysis of the experimental diets.

\begin{tabular}{|c|c|c|c|c|c|c|}
\hline \multirow{16}{*}{$\begin{array}{l}\text { Yellow Corn } \\
\text { Soy bean meal } 44 \% \\
\text { Corn gluten meal } \\
62 \% \\
\text { Soybean oil } \\
\text { Limestone } \\
\text { L-Lysine } \mathrm{HCl} \\
\text { DL-Methionine } \\
\mathrm{NaCl} \\
\text { Premix* } \\
\text { Sodium bicarbonate } \\
\text { Threonine } \\
\text { Dicalcium phosphate }\end{array}$} & \multicolumn{3}{|c|}{ High Protein } & \multicolumn{3}{|c|}{ Low Protein } \\
\hline & $\begin{array}{c}\text { Starter } \\
\%\end{array}$ & $\begin{array}{c}\text { Grower } \\
\%\end{array}$ & $\begin{array}{c}\text { Finisher } \\
\%\end{array}$ & $\begin{array}{c}\text { Starter } \\
\%\end{array}$ & $\begin{array}{c}\text { Grower } \\
\%\end{array}$ & $\begin{array}{c}\text { Finisher } \\
\%\end{array}$ \\
\hline & 53.50 & 56.60 & 60.60 & 57.40 & 61.77 & 63.60 \\
\hline & 35.20 & 33.30 & 27.00 & 30.97 & 27.60 & 24.60 \\
\hline & & & & & & \\
\hline & 3.40 & 1.30 & 3.70 & 4.40 & 3.00 & 3.40 \\
\hline & 3.80 & 4.80 & 4.70 & 3.00 & 3.50 & 4.30 \\
\hline & 1.10 & 1.00 & 1.00 & 1.10 & 1.00 & 1.10 \\
\hline & 0.17 & 0.17 & 0.17 & 0.30 & 0.30 & 0.17 \\
\hline & 0.25 & 0.25 & 0.25 & 0.25 & 0.25 & 0.25 \\
\hline & 0.35 & 0.35 & 0.35 & 0.35 & 0.35 & 0.35 \\
\hline & 0.30 & 0.30 & 0.30 & 0.30 & 0.30 & 0.30 \\
\hline & 0.20 & 0.20 & 0.20 & 0.20 & 0.20 & 0.20 \\
\hline & 0.03 & 0.03 & 0.03 & 0.03 & 0.03 & 0.03 \\
\hline & 1.70 & 1.70 & 1.70 & 1.70 & 1.70 & 1.70 \\
\hline & 100 & 100 & 100 & 100 & 100 & 100 \\
\hline \multicolumn{7}{|c|}{ Nutrient composition (analyzed values) } \\
\hline $\begin{array}{l}\text { Metabolizable } \\
\text { energy, Kcal/kg }\end{array}$ & 3050 & 3100 & 3180 & 3050 & 3100 & 3180 \\
\hline Crude protein, $\%$ & 22 & 20 & 19 & 21 & 19 & 18 \\
\hline Calcium, \% & 0.93 & 0.87 & 0.85 & 0.93 & 0.87 & 0.85 \\
\hline Phosphorus, \% & 0.44 & 0.43 & 0.42 & 0.44 & 0.43 & 0.42 \\
\hline Sodium, \% & 0.21 & 0.21 & 0.21 & 0.21 & 0.21 & 0.21 \\
\hline Chloride, \% & 0.25 & 0.25 & 0.25 & 0.25 & 0.25 & 0.25 \\
\hline Digestible Lys, \% & 1.22 & 1.12 & 0.96 & 1.22 & 1.12 & 0.96 \\
\hline
\end{tabular}

*The mixture supplied: retinol, $1.4 \mathrm{mg} / \mathrm{kg}$; DL- $\gamma$-tocopherol acetate, $6.5 \mathrm{mg} / \mathrm{kg}$; thiamine hydrochloride, $2.6 \mathrm{mg} / \mathrm{kg}$; riboflavin, $6.5 \mathrm{mg} / \mathrm{kg}$; pyridoxine hydrochloride, $1.30 \mathrm{mg} / \mathrm{kg}$; calcium D-pantothenate, $10.4 \mathrm{mg} / \mathrm{kg}$; nicotinic acid, $26 \mu \mathrm{mg} / \mathrm{kg}$; menadione sodium bisulfite, $650 \mu \mathrm{g} / \mathrm{kg}$; D-biotin, $70 \mu \mathrm{g} / \mathrm{kg}$; choline chloride, $780 \mu \mathrm{g} / \mathrm{kg}$; pteroylglutamic acid, $520 \mu \mathrm{g} / \mathrm{kg}$; cyanocobalamin, $26 \mu \mathrm{g} / \mathrm{kg}$; cholecalciferol, $13 \mu \mathrm{g} / \mathrm{kg}$. 
Table (2): Effect of feeding low or high CP on body weight gain (BWG), feed intake (FI) feed conversion ratio (FCR) and organs weight \% (Carcass weight, breast muscle weight, BMW; thigh muscle weight, TMW; liver weight, LW).

\begin{tabular}{|l|c|c|c|}
\hline & Low Protein & High Protein & Significance \\
\cline { 2 - 4 } Initial BW after 4-d-old (g) & $182 \pm 2$ & $183 \pm 3$ & $\mathrm{NS}$ \\
BWG (g/30day) & $1914 \pm 12$ & $1900 \pm 14$ & $\mathrm{NS}$ \\
FI (g/30 day) & $3235 \pm 34$ & $3255 \pm 26$ & $\mathrm{NS}$ \\
FCR & $1.69 \pm 0.2$ & $1.71 \pm 0.3$ & $\mathrm{NS}$ \\
Carcass weight (g/100g BW) & $73.4^{\mathrm{a}} \pm 1.1$ & $71.9^{\mathrm{b}} \pm 0.9$ & $*$ \\
BMW (g/100g BW) & $22.8^{\mathrm{a}} \pm 1.1$ & $21.1^{\mathrm{b}} \pm 0.9$ & $*$ \\
TMW(g/100g BW) & $15.4 \pm 0.8$ & $14.9 \pm 0.7$ & $\mathrm{NS}$ \\
LW(g/100g BW) & $1.88 \pm 0.04$ & $1.82 \pm 0.06$ & $\mathrm{NS}$ \\
Abdominal fat W(g/100g BW) & $1.52^{\mathrm{b}} \pm 0.04$ & $1.79^{\mathrm{a}} \pm 0.05$ & $*$ \\
\hline
\end{tabular}

Values are expressed as means \pm standard error; means with different superscripts differ from each other $(\mathrm{P} \leq 0 \cdot 05)$. BW, body weight; BWG, body weight gain; FI, feed intake; FCR, feed conversion ratio; BMW, breast muscle weight; TMW, thigh muscle weight; LW, liver weight.

Table (3): Effect of feeding low or high CP on nutrients digestibility.

\begin{tabular}{|l|c|c|c|}
\hline & Low Protein & High Protein & Significance \\
\cline { 2 - 4 } Dry matter digest, \% & $75.2 \pm 4.1$ & $74.9 \pm 5.2$ & NS \\
Crude protein digest, \% & $79.5^{\mathrm{a}} \pm 6.1$ & $73.4^{\mathrm{b}} \pm 4.6$ & $*$ \\
Crude fat digest, \% & $56.4 \pm 4.2$ & $57.1 \pm 2.6$ & NS \\
Crude fiber digest, \% & $28.9^{\mathrm{a}} \pm 3.2$ & $25.4^{\mathrm{b}} \pm 3.3$ & $*$ \\
\hline
\end{tabular}

Values are expressed as means \pm standard error; means with different superscripts differ from each other $(\mathrm{P} \leq 0 \cdot 05)$. 
Table (4): Input/output analysis and economical efficiency of growing chicks fed the low and high protein diets

\begin{tabular}{|l|c|c|}
\hline \multirow{2}{*}{ Feed cost (L.E) } & Low Protein & High Protein \\
\cline { 2 - 3 } Selling revenue (L.E) & & 12.044 \\
Net revenue (L.E) & 11.323 & 29.162 \\
E.E & 29.344 & 17.118 \\
R.E.E & 18.021 & 1.42 \\
\hline
\end{tabular}

${ }^{1}$ Feed cost $=$ number of $\mathrm{kg}$ feed per bird X price of $\mathrm{kg}$ feed (3.5 L.E for low protein diet and 3.7 L.E for high protein diet).

${ }^{2}$ Selling revenue $=$ body weight gain per bird $\mathrm{X}$ price of $\mathrm{kg}$ for live body weight chick (14 L.E).

${ }^{3}$ Net revenue $=$ difference between selling revenue and feed cost.

${ }^{4}$ E.E $($ Economic efficiency $)=$ net revenue/feed cost.

${ }^{5}$ R.E.E (Relative economic efficiency for 1ow protein diets), assuming high protein diets $=100 \%$ 
$\mathbf{A}$

B
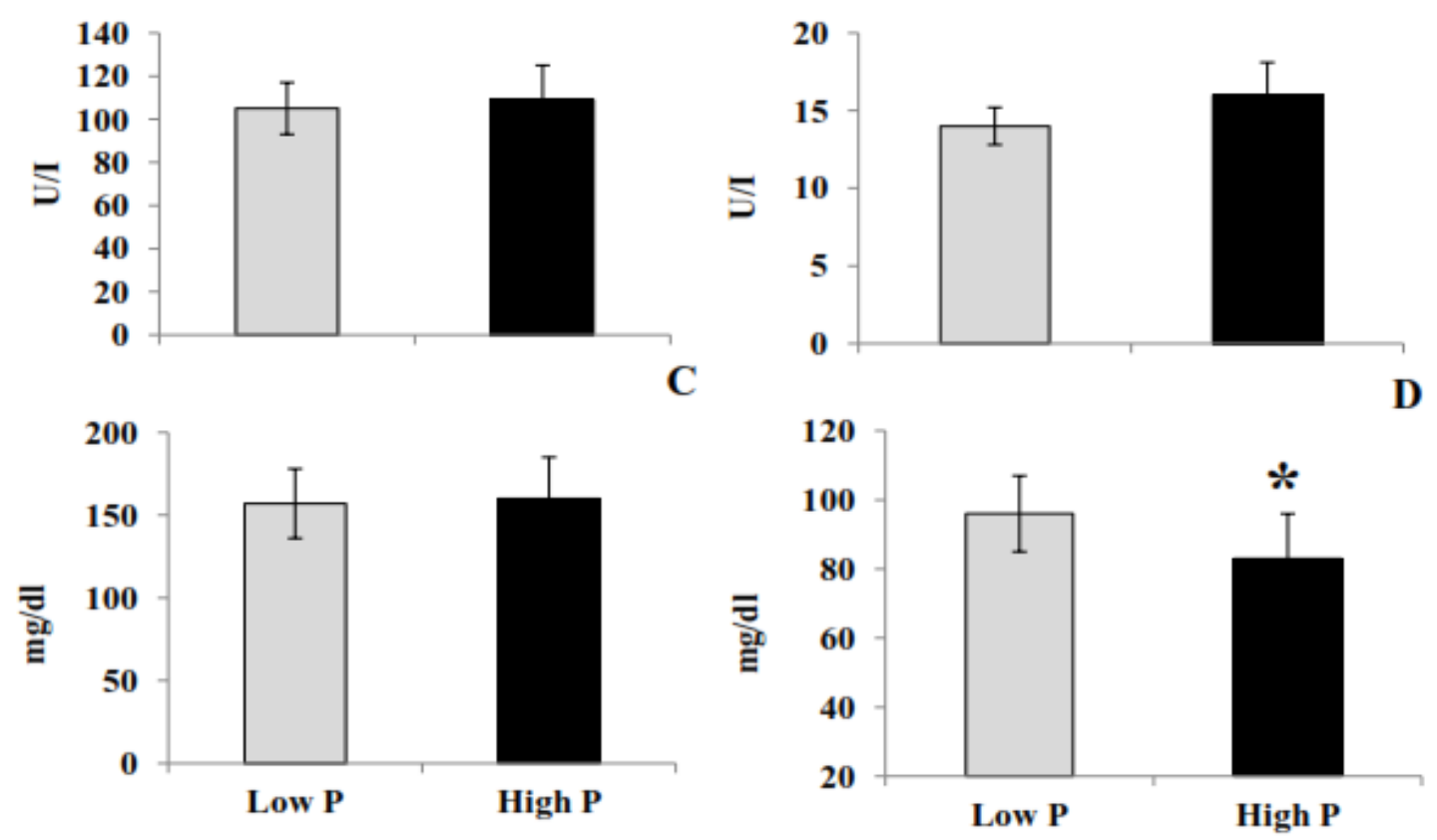

Figure 1. The effects of feeding low or high CP on plasma GOT (A), GPT (B), total cholesterol (C), HDL (D). Values are expressed as means \pm standard error; means with different superscripts differ from each other $(\mathrm{P} \leq 0 \cdot 05)$.
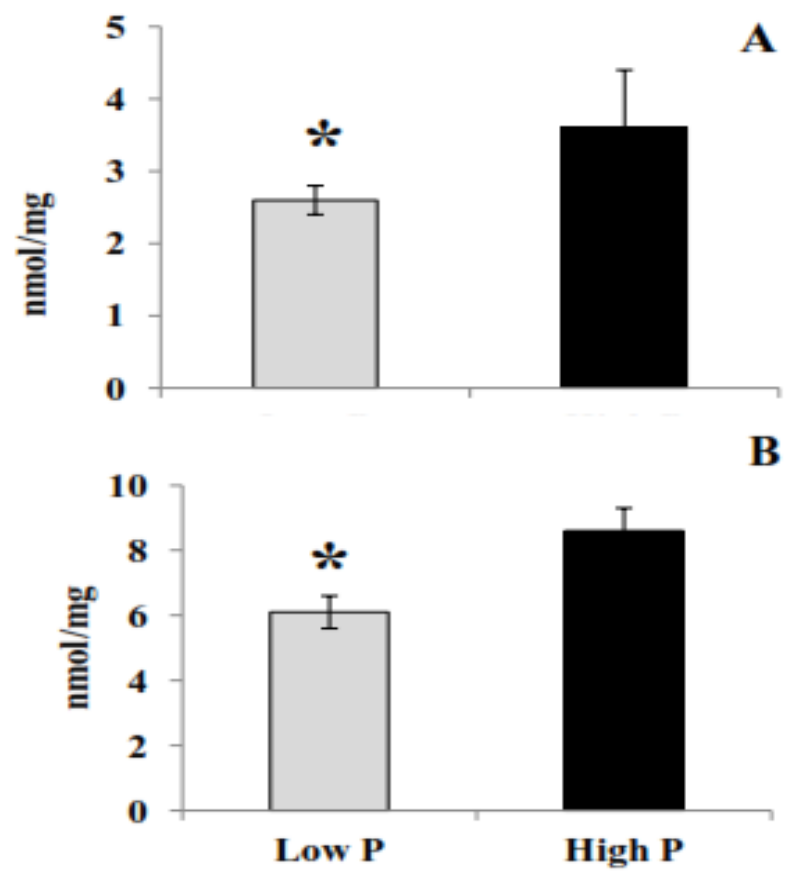

Figure 2. The effects of feeding low or high CP on muscle MDA (A) and liver MDA (B). Values are expressed as means \pm standard error; means with different superscripts differ from each other $(\mathrm{P} \leq 0 \cdot 05)$. 


\section{REFERENCES}

Aletor, V.A., Hamid, I.I., Niess, E., and Pfeffer, E. 2000. Low protein amino acids

supplemented diets in broiler chickens: Effects on performance, carcass characteristics, whole

body composition and efficiencies of nutrient utilization. J. Sci. Food Agric. 80:547-554.

AOAC (Association of Official Analytical Chemists). 1995. Official Methods of Analysis of the Association of Official Analytical Chemists. 16th ed. Assoc. Off. Anal. Chem., Arlington, VA.

balanced protein in broiler chickens. 1 . A flexible and practical tool to predict dose-response curves. Br. Poultry Sci. 46(3): 300-309.

Blair, R., Jacob, J.P., Ibrahim, S., and Wang, P. 1999. A quantitative assessment of reduced protein diets and supplements to improve nitrogen utilization. J. Appl. Poultr. Res. 8: 2547.

Bligh, E.G., Dyer, W.J. 1959. Fat extraction (cited by Pearson's chemical 1 analysis of foods). $8^{\text {th }} \mathrm{ed}$.

Bregendahl, K., Sell, J. L., and Zimmerman, D.R. 2002. Effect of lowprotein diets on growth performance and body composition of broiler chickens. Poult. Sci. 81:1156-1167.

Cobb Avian 48 management guide (2014) http://www.cobbvantress.com/products/cobb-avian48

Corzo, A., Mc Daniel, C.D., Kidd, M.T., Miller, E.R., Boren, B.B. and Fancher, B.I. 2004. Impact of dietary amino acid concentration on growth, carcass yield, and uniformity of broilers.

Australian J. Agri. Res. 55: 1133-1138.

Dairo, F. A. S., Adesehinwa, A. O. K., Oluwasola, T. A., and Oluyemi, J. A. 2010. High and low dietary energy and protein levels for broiler chickens. African J. Agricult. Res. 5: 2030-2038.

Dean, D.W., Bidner, T.D., and Southern, L.L. 2006. Glycine supplementation to low protein, amino acid-supplemented diets supports optimal performance of broiler chicks. Poult. Sci. 85:288-296.

Deschepper, K., and De Groote, G. 1995. Effect of dietary protein, essential and non-essential amino Acids on the performance and carcass composition of male broiler chickens. Br. J. Nutr. 36:229-245.

Eits, R.M., Giesen, G.W.G., Kwakkel, R.P., Verstegen, M.W.A, and Den Hartog, L.A. 2005. Dietary balanced protein in broiler chickens. 1. An Economic Analysis. Br. Poult. Sci. 46: $310-317$.

Fancher, B.I., and Jensen, L.S. 1989. Dietary protein level and essential amino acid content: Influence upon female broiler performance during the grower period. Poult. Sci. 68:897-908.

Ferguson, N.S., Gates, R.S., Taraba, J.L., Cantor, A.H., Pescatore, A.J., Ford, M.J. and Firman, J.D. 1994. Utilization of low protein diets for turkeys. Biokyowa Technical Review 7.

Firman, J.D., and Boling, S.D. 1998. Ideal protein in turkeys. Poult. Sci. 77: 105-110.

Gong, L.M., Lai, C.H., Qiao, S.Y., Defa Li, Ma, Y.X., and Liu Y. L. 2005. Growth Performance, Carcass Characteristics, Nutrient Digestibility and Serum Biochemical Parameters of Broilers Fed Low-protein Diets Supplemented with Various Ratios of Threonine to Lysine . Asian-Aust. J. Anim. Sci. 18: 1164-1170.

Hassan, I., A.G. Abdallah and S. Abo ElWafa, 1996. Utilization of decorticated local cottonseed meal in broiler diets. Egyptian Poult. Sci., 16: 31-49. 
Horniakova, E., and Abas K.A. 2009. Influence of Low Levels of Protein and Sex on Carcass Traits and Nutrient Content in Broiler Meats. Slovak J. Anim. Sci. 42: 7578.

Jimoh, F.O., Odutuga, A.A., and

Oladiji, A.T. 2005. Status of Lipid

Peroxidation and Antioxidant Enzymes in the Tissues of Rats Fed Low - Protein Diet. Pakistan J. Nutrit. 4 : 431-434.

Kamran, Z., Sarwar, M., Nisa, M. U., Nadeem, M. A., and Mahmood, S. 2010. Effect of low levels of dietary crude protein with constant metabolizable energy on nitrogen excretion, litter composition and blood parameters of broilers. Int. J. Agric. Biol. 12:401-405.

Kamran, Z., Sarwar, M., Nisa, M., Nadeem, M. A., Mahmood, S., Babar, M. E., and Ahmed, S. 2008. Effect of low-protein diets having constant energy-to-protein ratio on performance and carcass characteristics of broiler chickens from one to thirty-five days of age. Poult. Sci. 87:468-474.

Kidd, M.T., Kerr, B.J., Firman, J.D., and Boling, S.D. 1996. Growth and carcass characteristics of broilers fed low-protein, threonine-supplemented diets. J. Appl. Poultry Res. 5: 180-190.

May, J.D., Lott, B.D., and Simmons, J.D. 1998. The effect of environmental temperature and body weight on growth rate and feed:gain of male broilers. Poult. Sci. 77: 499-501.

Moran, E.T., and Stilborn, H. L. 1996. Effect of glutamic acid on broilers given submarginal crude protein with adequate essential amino acids using feeds high and low in potassium. Poult. Sci. 75:120-129.

Nahm, K.H. 2002. Efficient feed nutrient utilization to reduce pollutants in poultry and swine manure. Critical Rev. Environ. Sci. Tech. 32:1-16.

Nakaue, H.S., and Arscott, G.H. 1991. Feeding Poultry. In: Livestock Feeds and Feeding. 3 rd Ed. D.C. Church, Ed. Prentice Hall. Englewood Cliffs, New Jersey.

Namroud, N.F., Shivazad, M. and Zaghari, M. 2008. Effects of fortifying low crude protein diet with crystalline amino acids on performance, blood ammonia level, and excreta characteristics of broiler chicks. Poult. Sci. 87:2250-2258.

National Research Council. 1994. Nutrient requirements of poultry: Ninth revised edition. The National Academies Press, Washington, D.C. Available for purchase online at: http://www.nap.edu/catalog.php?record_ $\mathrm{id}=2114$.

Ohkawa, H.,Ohishi,N.,and Yagi, K.1979. Assay for lipid peroxides in animal tissues by thiobarbituric acid reaction. Anal. Biochem. 95: 351358.

Parr, J.F., and Summers, J.D. 1991. The effects of minimizing amino acid excesses in broiler diets. Poult. Sci. 70:1540-1549.

Rosebrough, R.W., Poch, S.M., Russell, B.A., and Richards, M.P. 2002. Dietary Protein Regulates In Vitro Lipogenesis and Lipogenic Gene Expression in Broilers. Comp. Biochem. Physiol., 132: 423-432.

Sterling, K.G., Vedenov, D.V., Pesti, G.M., and Bakalli, R. I. 2005. Economically optimal crude protein and lysine levels for starting broiler chicks. Poult. Sci. 84:29-36.

Swennen, Q., Janssens, G.P.J., Decuypere, E., and Buyse J. 2004. Effects of substitution between fat and protein on feed intake and its regulatory mechanisms in broiler chickens: energy and protein metabolism and diet-induced thermogenesis. Poult. Sci. 83: 19972004.

Waldroup, P.W., Jiang, Q., and Fritts, C.A. 2005a . Effects of glycine and threonine supplementation on 
performance of broiler chicks fed diets low in crude protein. Int. J. Poult. Sci. 4:250-257.

Waldroup, P. W., Jiang, Q., and Fritts, C. A. 2005b . Effects of supplementing broiler diets low in crude protein with essential and nonessential amino acids. Int. J. Poult. Sci. 4:425-431.

Yamazaki, M., Murakami, A., Yamazaki, M. and Takemsa, M. 1996. Reduction of nitrogen excreted from broiler chicks feeding low protein, amino acid supplemented diets. Japan. Poult. Sci. 33:249- 255.
Yamazaki, M., Murakami, H. and Takemasa, M. 1998. Effects of Ratios of Essential Amino Acids to Nonessential Amino Acids in Low Protein Diet on Nitrogen Excretion and Fat Deposition of Broiler Chicks. Japan. Poult. Sci., 35: 19- 26.

Yamazaki, M., Murakami, H., Nakashima, K., Abe, $H$. and Takemasa, M. 2006. Effect of Excess Essential Amino Acids in Low Protein Diet on Abdominal Fat Deposition and Nitrogen Excretion of the Broiler Chicks. Japan. Poult. Sci., 43: 150-155. 


\section{الملخص العربي}

تأثير التغذية علي علائق منخفضة في نسبة البروتين وثابتة في الطاقة علي الأداء الإنتاجي وخصائص الأبيحة ومعاملات الهضم وبلازما الام والكفاءة الإقتصادية في كتاكيت اللحم كب- أيفيان ^ء؛

$$
\begin{aligned}
& \text { أحمد على صالح }
\end{aligned}
$$

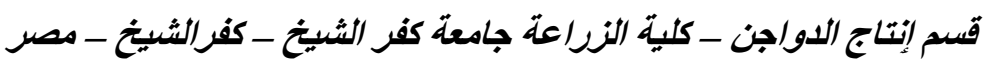

في هذا البحث تم در اسة تأثثر التغذية علي علائق منخفضة ومرتفعة في نسبة البروتين مع ثبات محتو اها من الطاقة و الاحتياجات من الاحماض الامينية علي الاداء الانتاجي وخصائص الذبيحة ومعاملات الهضم ودهون الدم لكتاكيت اللحم

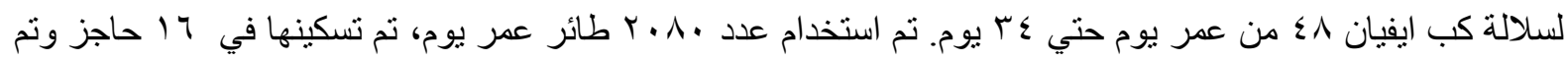
تحضين الطيور وتغذيتهم جميعا علي عليقة سوبر بادئ تحتوي علي بr\% بروتين و .90 كيلو كالوري طاقة لمدة ؟

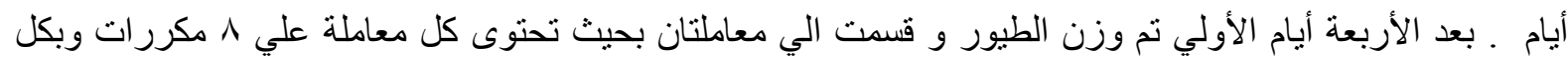

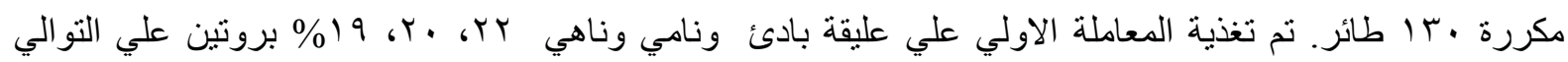

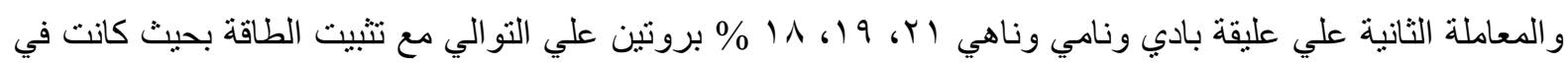

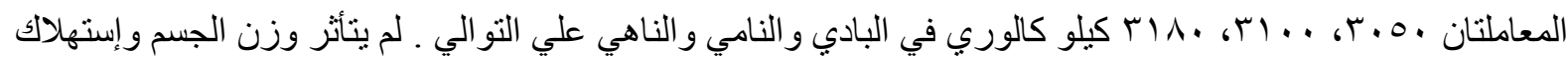

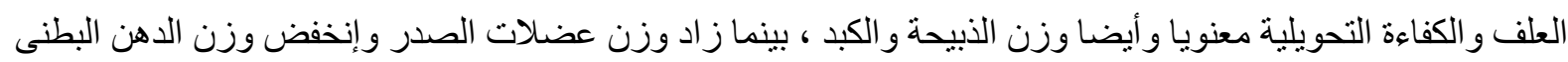

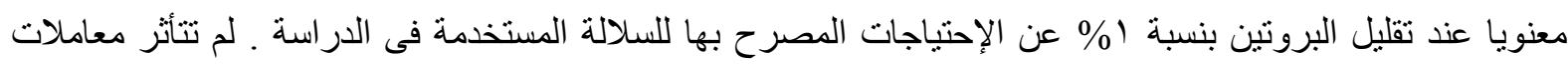
هضم المادة الجافة والدهون الخام لم تتاثر بينما تحسنت معاملات هضم البروتين و الالياف بانخفاض البروتين. لم تتخير

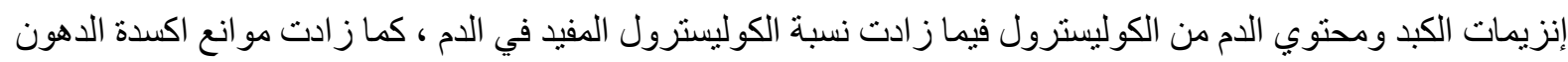
في اللحم و الكبد بانخفاض البروتين ـ يستتنج من الدر اسة أنه بخفض نسبة البروتين في علائق التسمين لسلالة كب ايفيان

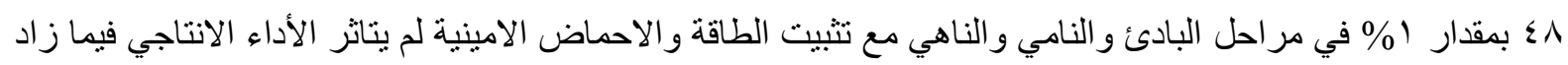
وزن عضلات الصدر وتحسن هضم البروتين والالياف مما له اثر جيد في خفض تكاليف التغذية لهذه السلالة في المستقبل 